\title{
Urgensi Sistem Pengawasan dalam Pelaksanaan Persidangan Secara Online
}

\author{
Miftakhul Ihwan ${ }^{1}$, Prasasti Dyah Nugraheni ${ }^{2}$ \\ ${ }^{1}$ Program studi ilmu Hukum, Fakultas Hukum, Universitas Negeri Semarang, \\ Sekaran, Gunung Pati, Semarang, Jawa Tengah 50229
}

Penulis untuk Korespondensi/E-mail: miftakhulihwan24@gmail.com

\begin{abstract}
The implementation of the online trial is a positive breakthrough solution in the midst of developments in information technology and in times of pandemics, will however the breakthrough had a negative impact, namely the instability of the network internet video teleconference, inadequate proof, the potential for hacking against persons who are not responsible, and prone to violations code of conduct by judges. Implementation online is a challenge for law enforcement or other institutions. The issue raised in This writing is how the implementation of online trials during the COVID-19 pandemic in the paradigm of critical theory? how is the monitoring system in online court practice in Indonesia?
\end{abstract}

Keyword: The Covid-19 Pandemic; Online Trials; Supervision

\begin{abstract}
Abstrak
Pelaksanaan persidangan online menjadi sebuah terobosan positif sebagai solusi di tengah perkembangan teknologi informasi dan di masa pandemi, akan tetapi terobosan tersebut memiliki dampak negatif yaitu tidak stabilnya jejaring internet video teleconference, kurang maksimalnya pembuktian, potensi peretasan terhadap oknum yang tidak bertanggung jawab, dan rawan terjadinya pelanggaran kode etik oleh hakim. Pelaksanaan secara daring menjadi tantangan tersendiri bagi penegak hukum atau institusi lainnya. Permasalahan yang diangkat dalam penulisan ini adalah Bagaimana pelaksanaan persidangan online di masa pandemi COVID-19 dalam paradigma critical theory? Bagaimana sistem pengawasan dalam praktek persidangan online di Indonesia?
\end{abstract}

Kata kunci: Pandemi Covid-19; Pengawasan; Persidangan Online;

\section{PENDAHULUAN}

Ditengah ganasnya penularan COVID-19 beberapa negara telah memberlakukan kebijakan social distancing bahkan lockdown, termasuk indonesia yang telah memberlakukan kebijakan social distancing. COVID-19 telah merubah berbagai sistem tatanan pemerintahan tanpa terkecuali termasuk dalam ranah peradilan. Penyebaran pandemi COVID-19 sampai sekarang masih tetap ada dan sulit rasanya dihilangkan, walaupun vaksin sudah ada akan tetapi belum dapat dipastikan kapan pandemi ini berakhir. Hal demikian juga dikatakan oleh jubir vaksinasi dan kementrian kesehatan (Saputra, 2020), dan untuk mencegah penyebaran tersebut Mahkamah Agung ikut andil dalam merespon situasi tersebut yaitu dengan dikeluarkannya Surat Edaran Nomor. 1 Tahun 2020 Tentang Pedoman Pelaksanaan Tugas Selama Masa Pencegahan Penyebaran COVID-19 di Lingkungan Mahkamah Agung dan Badan Peradilan di bawahnya kemudian diubah dengan SEMA No. 2 tahun 2020 dan diubah kembali dengan SEMA No. 3 tahun 2020. 
Dengan dikeluarkannya SEMA No. 1 tahun 2020 beserta perubahanya dan perjanjian kerjasama antara MA, Kementrian Hukum dan Ham, dan Kejaksaan Agung menyepakati untuk melaksanakan persidangan secara online. Dilansir dari kompas.com Kejaksaan Agung (kejagung) mencatat ada sekitar 179.912 perkara tindak pidana umum per tanggal 30 Maret-Juli 2020 telah diselenggarakannya persidangan online (Kompas.com, 2020).

Di era digitalisasi dan komputerisasi yang terjadi sekarang menjadikan semua kegiatan dimanfaatkan untuk se'efisien mungkin, era tersebut mempengaruhi di beberapa sektor termasuk sektor peradilan. Persidangan online menjadikan jawaban utama ditengah merebaknya ganasnya virus COVID-19, akan tetapi terobosan tersebut memiliki dampak negatif yaitu tidak stabilnya jejaring internet video teleconference, kurang maksimalnya pembuktian, potensi peretasan terhadap oknum yang tidak bertanggungjawab, dan rawan terjadinya pelanggaran kode etik oleh hakim. Setidaknya komisi yudisial menerima laporan terkait pelanggaran yang dilakukan oleh seorang hakim sebanyak 1.544 diantaranya terkait suap, korupsi dan kecurangan.

Selanjutnya dapat menimbulkan potensi adanya mal administrasi (Fatimah, 2020), yaitu penundaan berlarut minimnya sumber daya manusia dan ketidaktahuan hakim dalam mengoperasikan sistem juga dapat mengganggu kefokusan hakim dalam memimpin jalannya persidangan, ditambah lagi minimya keterbatasan kordinasi antar pihak, penasehat hukum tidak bisa secara langsung bertatap muka dengan kliennya.

Dalam pelaksanaan persidangan biasa saja masih banyak permasalahan yang muncul didalamnya, terlebih dengan beralihnya sistem pelaksanaan persidangan yang dilakukan secara daring yang masih relatif baru dan belum ada standarisasi teknis pelaksanaan persidangan online. sebuah terobosan baru mendatangkan tantangan dan peluang bagi eksistensi peradilan di Indonesia. Berdasarkan permasalahan tersebut maka penulis mengambil judul "URGENSI SISTEM PENGAWASAN DALAM PELAKSANAAN PERSIDANGAN SECARA ONLINE”.

\section{HASIL DAN PEMBAHASAN}

\section{Pelaksanaan Persidangan Online di Masa Pandemi COVID-19 dalam Paradigma Critical Theory}

Kehadiran pelaksanaan persidangan online ditengah pandemi COVID-19 merupakan sebagai dasar dalam keikutsertaan lembaga peradilan dalam memutus rantai penularan, hal demikian sesuai dengan Surat Edaran Nomor. 1 Tahun 2020 Tentang Pedoman Pelaksanaan Tugas Selama Masa Pencegahan Penyebaran COVID-19 di Lingkungan Mahkamah Agung dan Badan Peradilan di Bawahnya kemudian diubah dengan SEMA No. 2 tahun 2020 dan diubah kembali dengan SEMA No. 3 tahun 2020. Persidangan online menjadikan jawaban utama ditengah merebaknya ganasnya virus COVID-19, namun ada juga dampak negatif atas pelaksanaan tersebut. Oleh karena itu dalam merespon kehadiran pelaksanaan persidangan online maka perlu adanya bahan evaluasi yang cukup dalam hal ini melalui paradigma critical theory. Guba dan Denzim juga membagi paradigma penelitian dalam 5 bagian diantaranya yaitu positivism, post-positivisme, critical theory, kostruktivisme, dan partisipatoris, dari 5 paradigma tersebut penulis memakai paradigma critical theory yaitu dengan menggunakan beberapa teori-teori dalam menghasilan sebuah jawaban, teori tersebut diantaranya teori kepastian hukum dijadikan sebagai langkah untuk memberikan kepastian terhadap sebuah sistem persidangan yang dilaksanakan secara online sehingga para pencari keadilan mempercayai integritas penegak hukum, teori kemanfaatan hukum ditujukan untuk memberikan kemafaatan sebanyak-banayaknya.

Menurut Bleich (1977) teori kritis pertama kali dibangun oleh mazhab frankurt dimana teori kritis tersebut dimulai atas kritik terhadap aspek kehidupan (Malik \& Nugroho, 2016). Dalam praktik ilmu pengetahuan critical theory memiliki paradigma yang barangkali tidak mudah untuk ditukarkan dengan begitu saja. Critical theory memiki karakteristik sendiri dibandingkan paradigma lain. Realitas yang ada dan tidak sesuai dengan alur cerita, berdasarkan aturan hukum yang ada bersifat obyektivisme, netral dan dualistik adalah sikap mendasar dari paradigma critical theory untuk mengatakan hal tersebut semestinya tidak dijalankan seperti demikian sehingga memerlukan pelaksanaan 
yang jelas dan terukur (Faisal, 2014). Berikut teori yang digunakan dalam kepenulisan ini:

\section{a) Teori Kemanfaatan}

Dalam penelitian ini peneliti difokuskan dalam teori kemanfaatan dimana hukum dikonsepsikan sebagai penebar kemanfaatan kepada masyarakat banyak. Untuk mencapai kemanfatan kepada khalayak publik, dengan kata lain demi menyebarkan kemanfaatan sebanyak-banyaknya maka penelitian ini menggunakan teori kemanfaatan hukum. Manfaat hukum ditujukan tercapainya ketertiban dan ketentraman dalam kehidupan masyarakat. Tokoh indonesia juga tidak tinggal diam dalam menyampaikan pendapatnya tentang teori kemanfatan hukum, Satjipto Raharjo mengemukakan bahwa dalam teori kemanfatan hukum (kegunaaan) hukum bisa dipandang sebagai kemanfaatan yang hakiki serta arahan yang jelas terhadap hal yang kemungkinan baru ada (inovasi) (Rahardjo, 2014).

Teori kemanfaatan hukum sepaham dengan aliran utilitarianisme yang memiliki konsep mengedepankan kebahagian sebagai landasan dalam membuat hukum, dan pengamat dalam teori ini adalah Jeremi Bentham (1748-1831), persoalan yang dihadapi bentham pada waktu itu ialah bagaimana menilai baik buruknya sutau kebijakan sosial politik, ekonomi, hukum secara moral. Dengan kata lain bahwa dasar yang paling objektif adalah dengan melihat apakah suatu kebijakan/tindakan atau sebuah sistem tersebut membawa kemanfaatan yang begitu besar atau justru sebaliknya dapat menimbulkan kerugian bagi banyak orang (Erwin, 2016).

Aliran utilitarianisme merupakan aliran yang meletakan kemanfaatan hukum sebagai tujuan utama dari hukum itu sendiri, sehingga diharapkan pranata hukum dalam hal ini perangkat lembaga peradilan dapat mencapai kemanfaatan sebesar-besarnya kepada masyarakat khususnya para pencari keadilan walaupun sistem yang digunakan masih tergolong baru. Kemanfaatan merupakan hal yang paling utama dalam sebuah tujuan hukum, dengan demikian manusialah yang dapat mencapai tujuan itu sendiri dalam hal ini institusi-institusi pemerintahan khususnya para penegak hukum yang terlibat dalam pelaksanaan persidangan online, karena pada intinya hukum merupakan salah satu alat untuk menggapai tujuan hukum tersebut sehingga struktur hukum lah yang berperan penting dalam meraih tujuan hukum tersebut dan hukum mempunyai sasaran tersendiri terhadap harapan yang ingin dicapai.

\section{b) Teori Kepastian Hukum}

Menurut Sudikno Mertukusumo kepastian hukum diartikan sebagai jaminan bahwa hukum tersebut dapat dijalankan dengan baik (Mertukusumo, 2009). Karena, pada dasarnya kepastian sendiri merupakan hakikat tujuan hukum untuk mecapai sebuah harapan, dimana memerlukan langkah atau aturan atau sistem yang jelas. Kepastian hukum disini dapat menjadikan kehidupan keteraturan masyarakat dalam melakukan suatu tindakan atau perbuatan. Kepastian hukum juga ditujukan sebagai jalan dalam mencapai kepercayaan terhadap suatu tindakan hukum atau aturan hukum, dengan adanya kepastian hukum seseorang dapat melakukan suatu kegiatan atau tindakan dengan mudah melalui arahan yang jelas dan terukur. Dalam kepastian sangatlah erat hubungannya pada suatu kebenaran. Dengan demikian masyarakat akan tertib dan dengan hadirnya kepastian dapat mengarahkan kepada ketertiban (Sidharta, 2007).

Gustav redbruch mengumukakan 4 hal kepastian hukum 2 (dua) diantaranya adalah fakta, artinya didasarkan pada sebuah kenyataan, oleh karena demikian fakta harus dirumuskan dengan sistem yang jelas dan terukur sehingga dapat menghindari kekeliruan dan dapat di implementasikan dengan baik. Selain itu kepastian merupakan suatu hal (keadaan) yang pasti dan mempunyai arahan jelas terkait dengan ketentuan dan ketetapan. Hukum ditujukan untuk mendapatkan kepastian dan dapat memberikan kemanfaatan kepada masyarakat luas agar tidak ada yang merasa dirugikan. Kepastian hukum juga dihadirkan untuk mendapat fungsi hukum sebagaimana mestinya (Domnikus, 2010).

Kepastian hukum menjadi jamaninan terhadap seseorang, oleh karena itu tanpa adanya kepastian hukum yang ditentukan 
maka seseorang tidak memiliki ketentuan baku, begitu juga terahadap penegak hukum yang bertugas di peradilan, apabila sebuah hal yang baru atau inovasi tanpa adanya ketentuan baku didalamnya justru akan salah kaprah dalam melakukan tindakan tersebut mengingat tidak ada aturan yang jelas dalam melakukan sebuah tindakan. Oleh karenanya tidak salah apabila Gustav redbruch yang mengemukakan kepastian hukum merupakan bagian dari tujuan hukum. Dalam tatanan kehidupan masyarakat yang erat kaitannya dengan hukum terlebih ada sebuah sistem baru dalam hal ini pelaksanaan persidangan online, maka harus adanya jaminan bahwa bahwa sistem persidangan online tersebut sesuai dengan harapan sehingga pengawasan dalam berjalanya proses persidangan secara online dengan baik.

Kepastian hukum adalah hal yang bersifat normatif (Susanto, 2014) dalam pelaksanaanya baik ketentuan atau keputusan hakim. Kepastian hukum juga merujuk kepada pelaksanaan tata kehidupan yang dalam pelaksanaanya jelas, teratur, konsisten dan konsekuen.

\section{Sistem Pengawasan dalam Praktek Persidangan Online di Indonesia}

Sistem pengawasan merupakan jaminan sebuah proses dimana untuk memastikan organisasi dan manajemen tersebut tercapai sesuai ekspektasi. Sistem tersebut berkenaan dengan cara-cara agar suatu tujuan tersebut dapat berjalan dengan baik. Sistem pengawasan dihadirkan sebagai suatu tindakan untuk menilai apakah telah berjalan sesuai arahan atau justru menyimpang dari ketentuan.Sistem pengawasan juga sebaiknya diatur dalam aturan main dalam persidangan online seperti hal demikian sama seperti yang dilaksanakan oleh PTUN setelah UU AP disahkan, dimana dalam UU AP tersebut maka pengawasan diperluas dengan sedemikian rupa agar mencakup semua unsur dalam persidangan untuk menuju kearah future court sebagaimana dikemukakan oleh Bruce ton dan tentunya pengawasan tersebut harus berdasarkan pancasila, UUD NRI 1945 dan tujuan negara serta tujuan lembaga yudikatif (Putrijanti, Leonard, \& Utama, 2017).
Untuk itulah fungsi pengawasan dilaksanakan, agar memperoleh umpan balik (feed back) yang kemudian akan diperbaiki apabila terdapat keganjalan atau kekeliruan dalam berjalanya suatu pelaksanaan persidangan online sebagai pencegahan terjadinya permasalahan yang sukar untuk diperbaiki. Penulisan serupa tentang persidangan online sebelumnya sudah pernah ditulis dan dikaji, yaitu terkait dengan penelitian tentang urgensi diselenggarakanya persidangan secara elektronik selama masa pandemi COVID19, penulisnya adalah Dewi Anggraeni, bahwa beliau menyatakan persidangan elektronik perlu diterapkan bagaimana caranya agar persidangan elektronik tidak merugikan para pihak yang berperkara (Anggraeni, 2020).

Menurut Nonet - Selznick, menyebutkan bahwa dalam bentuk tatanan hukum yang ideal adalah tipe tatanan hukum yang otonomius, dimana hukum dipandang sebagai institusi mandiri yang dapat mengendalikan represi dan pada dasarnya melindungi integritasnya sendiri tanpa faktor lain yang menyertainya.

Keterlibatan elemen lembaga peradilan harus di ikutsertakan dalam pengawasan berjalanya persidangan online terutama KY, Komisi Yudisial (KY) merupakan sebuah lembaga yang dibentuk oleh negara atas dasar amanat dari konstitusi Negara, sebagai lembaga yang mempunyai tugas dan wewenang menjaga dan menegakan kehormatan, keluhuran martabat dan perilaku hakim. Peradilan menjadi hal yang utama dalam penegakan hukum dalam mementingkan kemaslahatan masyarakat.

Terkait wewenang Komisi Yudisial diatur dalam pasal 13 UU No.18/2011 Tentang Perubahan Atas UU No.22/2004 Tentang KY, mempunyai wewenang 1 (satu) diantaranya adalah menajga dan menegakan pelaksannaan Kode Etik dan/atau Pedoman Perilakuj Hakim (KEPPH). Komisi Yudisial juga mempunyai tugas yang diatur dalam pasal 20 UU No.18 Tahun 2011 Ayat (1) huruf a yaitu dalam rangka menjaga dan menegakan kehormatan, keluhuran martabat, serta perilaku hakim, Komisi Yudisial mempunyai tugas melakukan pemantauan dan pengawasan terhadap perilaku hakim. 
Selanjutnya keterlibatan peran Mahkamah Agung, sinergitas Mahkamah Agung dengan Komisi Yudisial sangat dinanti-nantikan, sebagai lembaga yang independen Mahkamah Agung mengeluarkan SEMA No.1 Tahun 2020 terkait Pedoman Pelaksanaan Tugas Selama Masa Pencegahan Penyebaran COVID-19 di Lingkungan Mahkamah Agung dan Badan Peradilan di Bawahnya.

Sebagai perwujudan sinergitas dengan Komisi Yudisial dan respon dari SEMA No. 1 Tahun 2020 beserta perubahanya maka pembentukan tim khusus dari Mahkamah Agung mutlak dibutuhkan demi adanya rasa kepastian hukum dan dapat memberikan kemanfaatan sebanyak-banyaknya.

Berdasarkan SEMA No.1 Tahun 2020 seluruh pimpinan, hakim, dan aparatur peradilan pada Mahkamah Agung untuk menyesuaikan sistem kerja dengan berpedoman pada Surat Edaran Menteri Pendayagunaan Aparatur Sipil Negara dalam upaya pencegahan penyebaran COVID-19 dalam lingkungan instansi pemerintah. Adanya peraturan tersebut dalam menjalankan tugas kedinasan dilakukan di rumah atau WFH.

\section{KESIMPULAN}

Uraian Berbagai regulasi telah diterapkan untuk memutus rantai penularan secara berlebihan termasuk dihadirkannya pelaksanaan persidangan secara online, akan tetapi nampaknya hal demikian perlu ditelisik lebih jauh. Tentunya dalam pelaksanaan persidangan secara online akan muncul berbagai masalah baru yang ditimbulkan, seperti kendala jaringan, adanya potensi pelanggaran kode etik hakim, maladministrasi dan permasalahan lainnya. Penegak hukum menjadi leading sektor dalam berjalannya pelaksanaan persidangan online dan institusi-institusi lembaga yudikatif mempunyai tanggungjawab penuh atas pelaksanaan tersebut.Nampaknya pelaksanaan persidangan tersebut masih perlu berbenah pasalnya belum dihadirkanya aturan standarisasi pelaksanaan persidangan online dan belum adanya aturan yang jelas terkait dengan teknis pelaksanaanya.Melalui paradigma critical theory dengan teori yang digunakan teori kepastian hukum, dan teori kemanfaatan hukum maka untuk menuju kepastian dan kemanfaatan dalam praktek persidangan online diperlukannya sistem pengawasan untuk dijadikan bahan evaluasi demi menghindari permasalahanpermasalahan yang sukar untuk diselesaikan.

Sehingga perlunya keterlibatan Komisi Yudisial dalam pelaksanaan persidangan online sebagai amanat konstitusi pasal 24B Ayat (1) UUD NRI tahun 1945 dan perlu adanya tindakan nyata oleh Mahkamah Agung dalam merespon atas pelaksanaan persidangan secara online yaitu dengan membentuk sebuah tim Sumber Daya Manusia yang berkompeten dalam bidang IT dengan mengikutsertakan peran Komisi Yudisial atau setidaknya melaksanaan kerja sama dengan lembaga lain, serta merancang aturan baru terkait teknis persidangan online sebagai perwujudan asas kepastian sehingga dapat memberikan rasa percaya dan dapat memberikan kemanfaatan ke sebanyakbanyaknya orang terkhusus para pencari keadilan melalui peran institusi penegak hukum.

\section{REFERENSI}

Anggraeni, R. D. (2020). Wabah Pandemi Covid-19, Urgensi Pelaksanaan Sidang Secara Elektronik. 'ADALAH, Vol 4 No 1.

Domnikus, R. (2010). Filsafat Hukum Mencari: Memahami Dan Memahami Hukum. Yogyakarta: Laksbang Pressindo.

Erwin, M. (2016). Filsafat hukum: Refleksi Kritis Terhadap Hukum dan Hukum Indonesia (dalam dimensi ide dan aplikasi). Jakarta: Rajawali .

Faisal. (2014). Menelusuri Teori Chaos dalam Hukum Melalui Paradigma Critical Theory. Yustisia, Volume 3 No 2.

Fatimah, S. (2020, Juni 10). Ombudsman RI Temukan Potensi Maladministrasi Sidang 
Virtual. Retrieved from Ombudsman RI : https://www.ombudsman.go.id/news/r/ombu dsman-ri-temukan-potensi-maladministrasisidang-virtual

Kompas.com. (2020, Juli 08). Kejagung: Ada 176.912 Sidang Online Tipidum Selama Pandemi Covid-19. Retrieved from Kompas.com:

https://nasional.kompas.com/read/2020/07/0 8/11355211/kejagung-ada-176912-sidangonline-tipidum-selama-pandemi-covid-19

Malik, A., \& Nugroho, A. D. (2016). Menuju Paradigma Penelitian Sosiologi yang Integratif. Sosiologi Reflektif, Volume 10 No 2.

Mertukusumo, S. (2009). Penemuan Hukum. Yogyakarta: Liberty.

Putrijanti, A., Leonard, L. T., \& Utama, K. W. (2017). Model Fungsi Pengawasan Oleh Pengadilan Tata Usaha Negara Sebagai
Upaya Menuju Tata Kelola Pemerintah yang Baik. Mimbar Hukum, Volume 29 No 2.

Rahardjo, S. (2014). Ilmu Hukum. Bandung: PT. Citra Aditya.

Saputra, M. G. (2020, Desember 16). Belum Bisa Dipastikan Kapan Pandemi Covid-19 Berakhir. Retrieved from Merdeka.com: https://www.merdeka.com/peristiwa/belumbisa-dipastikan-kapan-pandemi-covid-19berakhir.html

Sidharta, A. (2007). Teori Hukum dan Filsafat Hukum. Bandung: PT. Refika Aditama.

Susanto, N. A. (2014). Dimensi Aksiologis Dari Putusan Kasus "St" Kajian Putusan Peninjauan Kembali Nomor 97 Pk/Pid.Sus/2012. Jurnal Yudisial, Volume 7 Nomor 3. 